\title{
Observations on the Superb Pitta Pitta superba and other Manus endemics
}

\author{
GUY C. L. DUTSON and JONATHAN L. NEWMAN
}

\section{Summary}

The Superb Pitta Pitta superba, an almost wholly unknown rainforest endemic of Manus Island, Papua New Guinea, was investigated in June/July 1990. On the basis of its call, a rising then falling whistle given twice, it appears to occur at low densities and may be restricted to hillier areas where stones can help break snail shells. The snake Boiga irregularis may affect this and one other Manus endemic bird.

\section{Introduction}

The Superb Pitta Pitta superba was treated as "threatened" in a recent global review, which noted no recent sightings (Collar and Andrew 1988). It is endemic to the island of Manus, off the north coast of Papua New Guinea (Figure 1). At the suggestion of ICBP, the Cambridge Solomons Rainforest Project, a student expedition, spent three weeks investigating this species on Manus in 1990.

Manus is an isolated island of $1,943 \mathrm{~km}^{2}$ which, together with a scatter of small satellite islands, comprise the Admiralty Islands, administered as Manus Prov-

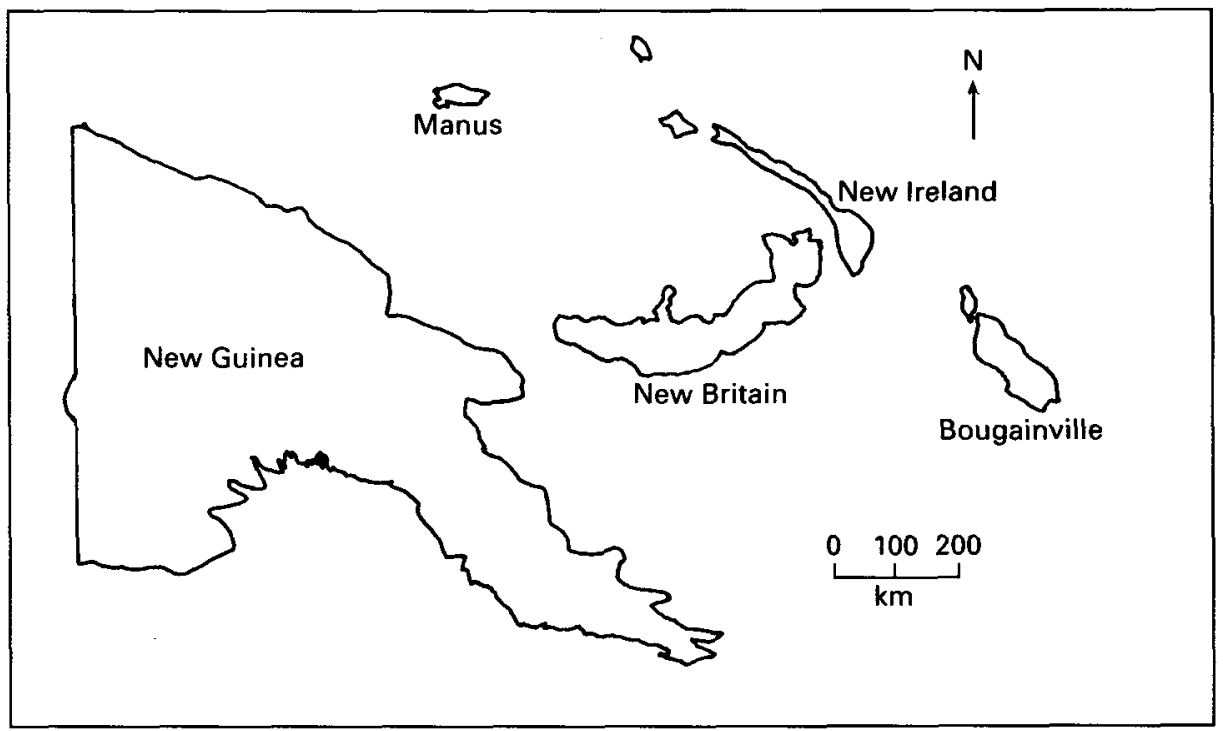

Figure 1. Papua New Guinea. 
ince. The hilly terrain is covered in rainforest up to the maximum altitude of $702 \mathrm{~m}$, with no reported avifaunal changes with altitude. Rainfall is around $4,000 \mathrm{~mm}$ spread evenly throughout the year with no predictable seasons. The population of about 26,000 (1980 figure; Kula et al. undated) consists largely of subsistence farmers concentrated along the coast and the one inland road, although a substantial minority work in the provincial capital Lorengau and a significant income derives from emigrant workers elsewhere in Papua New Guinea. The forest is being eroded by shifting cultivation, although this is still on a relatively small scale, and by a $211 \mathrm{~km}^{2}$ logging concession in the west. An estimated $80 \%$ of the island was primary forest in 1987 (Kula et al. undated).

\section{Methods and coverage}

A general survey of the forest birds of Manus, with a major emphasis on locating the Superb Pitta, was conducted by the authors between 28 June and 21 July 1990. Extensive observations were made in $20 \mathrm{~km}^{2}$ of forest at $0-205 \mathrm{~m}$ altitude between Rossun (= Warembu) village and Lorengau (Figure 2). Primary forest, comprising about $5 \mathrm{~km}^{2}$ of this study area, was visited on 13 days but visits were often curtailed by frequent rainstorms. Village people along the main road across east Manus to the village of Tingau were questioned as to the occurrence of the Superb Pitta. The vantage point referred to below was an open hilltop cultivated by one family (perhaps $2 \mathrm{ha}$ ), somewhat higher than the surrounding primary forest.

A small population of Superb Pittas was recorded at about $100 \mathrm{~m}$ altitude, $2 \mathrm{~km}$ north of Rossun village (at $2^{\circ} \mathrm{O}^{\prime} \mathrm{S} 147^{\circ} 15^{\prime} \mathrm{E}$ ).

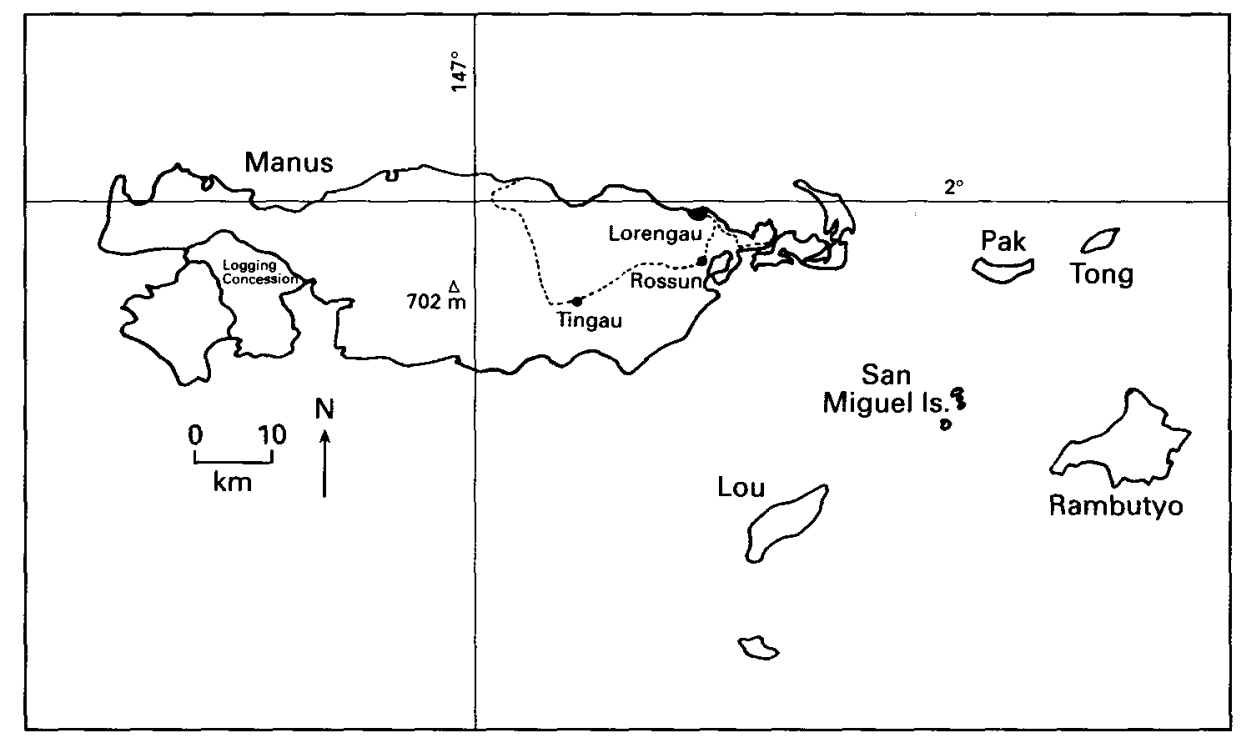

Figure 2. Manus Island. 


\section{Vocalizations}

All our records of Superb Pitta were of birds that were calling. The call was not heard during the first two and a half weeks on Manus, despite visiting apparently suitable habitat. Manus has a distinct paucity of forest species such that the call of the Superb Pitta was quite distinctive once we were familiar with the wide repertoire of Manus Friarbird Philemon albitorques. The call is loud and clear, audible over an estimated $800 \mathrm{~m}$ from the vantage point. As seen from the sonagram (Figure 3), it is a clear whistle consisting of two identical notes, each rising then falling in pitch and gradually declining in volume.

Occasional calls were heard in the late afternoon. According to the knowledgeable family living on the vantage point from which all our records originated, Superb Pittas called most mornings and late afternoons. This family were all competent and practised at imitating this call and would call continuously to attract the pittas up close to their house and to keep them calling to aid us seeing the birds. Birds appeared to be attracted from over $600 \mathrm{~m}$ away right up to the house. Of the three that appeared to be present, one called for about $60 \%$ of the time that calls were being imitated, another bird for about $30 \%$ of the time and a third very rarely. Only the most frequently calling bird approached the vantage point closely, calling repeatedly from degraded forest only $20 \mathrm{~m}$ from the family's house. Such behaviour suggests this bird to be more territorially active than the others and presumably the male of a family group. Whether the other calling birds were individuals in the same family group or adjacent males was not determined, although the second bird overlapped in range with the first on several occasions.

Local people, wishing to find Superb Pittas for us, indicated several calls erroneously, including Mackinlay's Cuckoo-dove Macropygia mackinlayi, even when the calling bird was visible in the treetops. This confusion was presumably due to the fact that the local names for both species are the same ("kuku"), although the calls are quite different. The call of $M$. mackinlayi resembles that of the European Cuckoo Cuculus canorus, being disyllabic, with the second syllable lower than the first. The call of the pitta was described by W. S. Peckover in Coates (1990) as resembling the "coo-coo" call of Beccari's Ground-dove Gallicolumba beccarii, a call with which we are not familiar. However, the descriptions of this species in Coates (1985) and Beehler et al. (1986) seem most unlike Superb Pitta. Peckover (in litt. 1991) has suggested that this call, an identification made by a local guide, may indeed refer to Beccari's Ground-dove.

Two quieter calls were heard at close range from Superb Pittas. A chicken-like
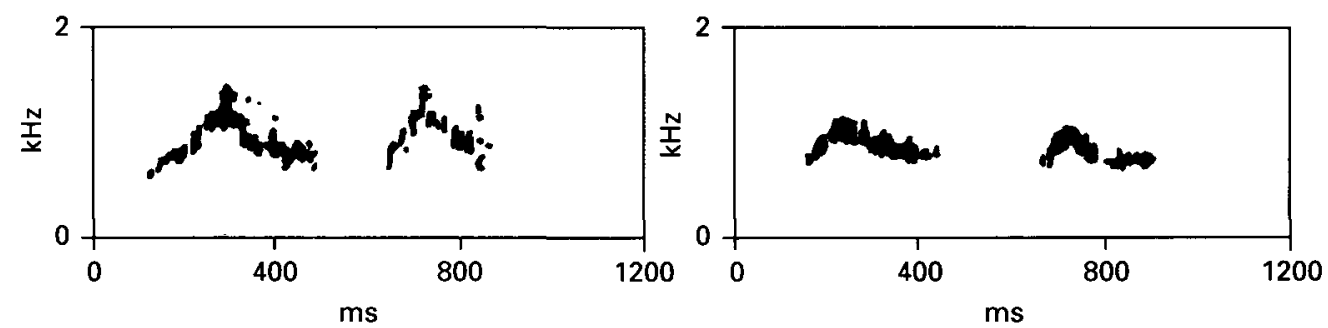

Figure 3. Sonagrams of the typical call of Superb Pitta. 
"gwark" was heard repeated at intervals of a few tens of seconds, perhaps only by birds on the ground. This call was heard whilst stalking birds known to be nearby; it carried over a distance of only about $20 \mathrm{~m}$. No bird was actually seen to utter this call, its origin concluded from overwhelming circumstantial evidence. Similarly, a repeated series of slightly louder "gwark" notes was occasionally heard in similar circumstances.

\section{Sightings}

The Superb Pitta was seen only when the typical call was followed up. One to two birds called continuously when imitated and could be approached carefully to within to to $30 \mathrm{~m}$ before they flew off to call again from another perch. Actually seeing Superb Pittas was, however, much harder. Birds slipped away unseen on about ro occasions, were seen only in flight four times and seen perched twice. Calling was always from an elevated perch, between 2 and $7 \mathrm{~m}$ above ground when located $(n=4)$. The two perched sightings were on the middle of a lowest branch of a small canopy sapling, and on the outer of a lowest branch of an understorey tree. Between perches, birds flew at 2-7 $\mathrm{m}$ above the ground with whirring wings, a sound that could be confused with the whirrs of the common Metallic Starling Aplonis metallica, although a sighting, even in silhouette, was distinctive.

Tape-luring, using recordings of the local children's imitations, helped in obtaining close views of the bird. On one occasion, a bird flew in and landed on a small shrub less than $3 \mathrm{~m}$ away from a sitting observer. The bird called in response to the tape before flying back to a higher perch.

When seen calling, the Superb Pitta lowered and partially opened its wings and appeared to be straining considerably. On take-off when fleeing the observer, the bird toppled forward exposing the red undertail-coverts. Plumage is glossy black with bright blood-red undertail-coverts and bright pale blue upperwing coverts. In flight, these colours were often not discernible. Sexes are reportedly similar, although females are slightly smaller and less bright (Rothschild and Hartert 1914).

\section{Local reports}

Local farmers and fishermen in the villages around Rossun were familiar with the bird as "kuku". The species seemed to have an almost mythical status, with even the younger generations familiar with it and repeating a standard description of its nesting habits. They say that the bird changes the direction of its nestentrance with a changing wind so that the nest is always draught-free. Presumably it is meant that the nest is built to open away from the direction of the winds prevailing at the time of nest-building, as recorded by $\mathrm{E}$. Lindgren in Coates (1990). Descriptions of a nest with eggs found on 11 October 1913 are given in Rothschild and Hartert (1914). Local information cites snake predation of nests as a major factor in the rarity of the Superb Pitta. Two species of snake are commonly recorded on Manus, a native terrestrial ground boa Candoia aspera and the possibly introduced Brown Tree Snake Boiga irregularis (pers. obs., Australian Museum specimens, Kisokau 1980). 
The Superb Pitta was said to feed on snails, smashing them on stones used as anvils. One possible anvil was seen, a flat round stone of about $10 \mathrm{~cm}$ diameter, with fragments of three old shells around, each about $1 \mathrm{~cm}$ diameter. Other pitta species are recorded to use stones as anvils (e.g. Bruce 1985). This behaviour is perhaps commoner in the larger species, Round et al. (1989) noting a much higher proportion of snails in the diet of Giant Pitta $P$. caerulea than Gurney's Pitta $P$. gurneyi in Thailand. A less reliable informant claimed that superba actually fed on water snails on rocks in small forest streams.

Actual sightings by local people, as opposed to second-hand records, were rare. Only two apparently genuine records were reported by people in Rossun, a village of about 150 inhabitants, all primarily subsistence farmers except for two with town jobs. One concerned a bird caught at the nest and sold to soldiers during the Second World War. The other was of a bird shot for its beautiful plumage by a local hunter. The brother of this hunter, a villager who showed considerable interest in and aptitude for natural history, claimed the species to be present but heard only rarely at the site at which this bird was shot, about $2 \mathrm{~km}$ from our sightings (Figure 2). Other records could all have been confusion with other species.

Local people around the village of Tingau, the furthest east travelled, also knew of the "kuku" and repeated the story about its nesting habits. They claimed to be able to show us a nest if given enough time, around a month, in which to locate one. Whether such reports were genuine was difficult to determine.

\section{Previous records}

Most specimen records of the Superb Pitta are recorded as Manus with no more details of location, altitude or habitat. The species is relatively well represented in early collections with the type series consisting of 29 birds taken over two months (Rothschild and Hartert 1914). There are no records from other islands in the Admiralty archipelago, unlike some other endemics (e.g. Manus Pied Monarch Monarcha infelix).

Recent records of the species are a sighting in 1975 by E. Lindgren and J. Iruru and two mist-netted in 1988 by W. S. Peckover and M. LeCroy (Coates 1990), close to the 1990 sightings. There is an unconfirmed field record in 1989 in the same area (Hicks and Hicks in press).

\section{Habitat preference}

Since the species has been recorded from so few sites recently, it is important to identify the constraining factors. Habitat loss and fragmentation seem unlikely considering the small scale of such activities on Manus. Predation by domestic animals would appear unlikely to be a major factor considering the presence of native snakes and long-established feral pigs throughout the forest.

The family living at the 1990 Superb Pitta site suggested that the forest there was more open and that the species preferred hilltop forest. It was also suggested that this hilltop forest must be adjacent to a reasonably large river, a difficult criterion to meet, especially on a small island with few large rivers. 
Restriction to hills was independently suggested by another village elder. A reason for the need for open forest may be the species's use of stones as anvils. Such stones are perhaps most commonly found on riversides or eroded hill tops.

The 1990 site was gently sloping primary forest around a small patchily cultivated hilltop about $\mathrm{I} \mathrm{km}$ from the road. Disturbance was not insignificant, however, with a few paths and occasional felled trees in the area from which the species called. A hunting party cutting down several trees in search of sleeping spotted cuscus Phalanger maculata apparently disturbed the Superb Pittas such that no calls were heard that day. The forest immediately adjacent to the vantage point appeared much richer in animal life, although this was perhaps an effect of the ecotone. Nonetheless, forest passerines were in the order of twice as common as elsewhere on Manus and cuscus and ground boas several times commoner. Restriction of Superb Pittas to primary forest was frequently suggested to us, although this conflicts with the report of a nest found in light secondary forest (Coates 1990), and the individual seen around the vantage point was lured into recent secondary forest, heavily invaded with bamboo. All other records of the species have been from or adjacent to extensive primary forest.

\section{Population}

The minimum population at the 1990 site was assumed to be three birds, the maximum number heard calling. Based on an audibility distance of $800 \mathrm{~m}$ for the call, no more than these three calling birds were using an area of $3.5 \mathrm{~km}^{2}$, of which about $80 \%$ was primary forest.

Assuming that the Superb Pitta is restricted to primary forest, then extrapolation of the three calling birds in the study site indicates an approximate world population of 1,000 calling birds. The proportion of birds that were calling is, however, unknown. There may not be a defined breeding season, as suggested by the climatic aseasonality and scattering of breeding records of other forest species (pers. obs.) on Manus, although Rothschild and Hartert (1914) recorded one nest with eggs and two juvenile birds in September-October.

More realistic, however, is to assume an as-yet unidentified habitat preference or prerequisite (for example, for hilltop forest), resulting in the observed paucity of records and a much lower overall population. It is of particular concern to note the limited area in which there have ever been any records.

\section{Conservation and further research}

As a priority, the population level of the species must be clarified. This requires knowledge of its range on Manus and some idea of population density, based on fieldwork during the season of maximal calling.

Based on the recent sightings of the Superb Pitta and our lack of records from extensive patchy forest around Rossun, it is assumed that the species is dependent on primary forest. Logging and forestry proposals on Manus must therefore be monitored. At present, most villagers, especially the better educated individuals, are firmly against logging on their land. Furthermore, unfulfilled promises of community help by a logging company currently work- 
ing the concession in west Manus have further convinced locals of the undesirability of logging. However, large-scale schemes could be imposed by the dealings of higher officials, as is happening elsewhere in the region. The locally preferred option of selective felling of trees with a "walk-about saw-mill" is unlikely to reach detrimental levels beyond the immediate environs of villages.

Agriculture is currently restricted to roadsides. Although farmers may prefer the well-drained soils inhabited by the species this is likely to be a minor factor in the short term.

Hunting is also not thought to be a threat. Occasional birds will undoubtedly be taken for their beauty but, unless an overseas market opens up, the difficulty of finding the species should protect it. Conversely, the beauty of the species makes it a nu...ral centrepiece of conservation education campaigns, and could generate considerable local pride and goodwill.

In summary, the Superb Pitta habitat should be safe in the short term because of the educated opinion most locals have of logging. However, the species seems inexplicably rare. If it indeed has a very small or declining population, then the smallest forest loss through forestry or agriculture could seriously imperil this splendid bird.

\section{Other Manus endemics}

The Admiralty Islands have five endemic bird species and two distinctive subspecies sometimes treated as endemics (e.g. Coates 1985, 1990). With such small geographical ranges, all may be threatened to some extent. During our survey, however, the Manus Friarbird and Meek's Pygmy-parrot Micropsitta meeki were both common, especially in degraded forest, and appear therefore to be at no risk. The Manus Pied Monarch is fairly common, with an encounter rate of around one per hour in high forest, but much less able to tolerate secondary forest. The Manus Boobook Ninox meeki appeared to tolerate highly degraded forest, including riverine cultivation and areas around villages, but occurs at much lower population densities than most of the other endemics. A maximum of three heard along a $3 \mathrm{~km}$ transect through secondary forest indicated a reasonable population. However, the endemic subspecies of Masked Owl Tyto (novachollandae) manusi has not been recorded recently, perhaps because of the unobtrusiveness of this species.

A clue to the present scarcity of the Superb Pitta may be indicated by the inexplicable change in status of the endemic subspecies of Rufous Fantail Rhipidura (rufifrons) semirubra. Despite visits by experienced birders, this subspecies has not been seen on Manus since 1934 when it was described as "common everywhere in true forest and secondary bush" (unpublished manuscript in American Museum of Natural History). There are recent records of this subspecies only from the nearby small island of Tong (in Coates 1990), and although it may also occur on San Miguel, both are tiny islands. The decline of this bird may be related to the presence of the Brown Tree Snake on mainland Manus. This species was introduced to Guam where it has been responsible for the decimation of forest birds (Savidge 1987). Indeed, the population density of all forest 
passerines on Manus was exceptionally low (R. K. Hicks pers. comm. 1990; pers. obs.). A similar scenario to Guam could be affecting the avifauna of Manus.

\section{Acknowledgements}

We would like to thank the following for their invaluable help in the field and advice on our results: Dave Buckingham, Dr Nigel Collar, Prof. Jared Diamond, Karol Kisokau, Ron Knight, Bill Peckover and all the inhabitants of Rossun village, particularly Adam Jonathan and Solomon. We are most grateful to our generous sponsors: ICBP/FFPS, Cable and Wireless plc, Cotton Trust, New York Explorers' Club (Youth Activity Fund), Selwyn College, People's Trust for Endangered Species, British Ornithologists' Union, Godinton Trust, Ernest Kleinwort Charitable Trust, Radley Charitable Trust, A. J. Burton 1956 Charitable Settlement, Condor Conservation Trust, Bartle-Frere Exhibition, Trinity Hall, Mary Euphrasia Mosley Trust, Cambridge Expeditions Fund, Vincent Trust, Spicers plc, L. A. Cadbury Charitable Trust, The Wall Charitable Trust, Rayne Foundation, D. M. Charitable Trust, Interpret, A. S. Butler Charitable Trust, King Edward's School Birmingham, R. and M. Foreman Charitable Trust and Whitley Animal Protection Trust. Richard Ranft of the British Library of Wildlife Sounds kindly prepared the sonagram.

\section{References}

Bruce, M. D. (1985) Pitta. Pp. $464-465$ in B. Campbell and E. Lack, eds. A dictionary of birds. Calton (Staffordshire): T. and A. D. Poyser.

Coates, B. J. (1985) The birds of Papua New Guinea, 1. Alderley, Queensland: Dove Publications.

Coates, B. J. (1990) The birds of Papua New Guinea, 2. Alderley, Queensland: Dove Publications.

Collar, N. J. and Andrew, P. (1988) Birds to watch: the ICBP world checklist of threatened birds. Cambridge, U.K.: International Council for Bird Preservation (Techn. Publ. 8).

Hicks, R. K. and Hicks, J. H. (in press) In search of the Manus endemics. Muruk 5.

Kisokau, K. M. (1980) Manus Province: a biophysical resources inventory. Port Moresby, Papua New Guinea: Office of Environment and Conservation.

Kula, G. R., Kinbag, F. and Unkau, C. (undated) Fauna survey report on west coast timber area, Manus Province. Boroko, Papua New Guinea: Dept of Environment and Conservation (Conservation Study Report no. 2).

Round, P. D., Treesucon, U. and Eames, J. C. (1989) Giant Pitta Pitta caerulea nesting in Thailand. Forktail 5: 35-47.

Rothschild, W. and Hartert, E. (1914) The birds of the Admiralty Islands, north of German New Guinea. Novit. Zool. 21: 281-298.

Savidge, J. A. (1987) Extinction of an island forest avifauna by an introduced snake. Ecology 68: $660-668$.

GUY C. L. DUTSON

Selwyn College, Cambridge $\mathrm{CB}_{3} 9 \mathrm{DQ}, U . K$.

JONATHAN L. NEWMAN

Trinity Hall, Cambridge CB2 ITJ, U.K. 